\title{
PENERAPAN LEKSIKON KRAMA INGGIL OLEH GENERASI MUDA BERDASARKAN TINGKAT PENDIDIKAN SEBAGAI IMPLEMENTASI SUBASITA DI KUDUS
}

\author{
Sabbihisma Debby Satiti
}

Email : sabbihisma.d@.mail.ugm.ac.id

Fakultas Ilmu Budaya, Universitas Gadjah Mada, Yogyakarta, Indonesia

\section{Article history}

Received

Revised

Accepted

Keywords

Education level

Krama inggil

Lexicon

Subasita

Young generation
This study examines the application of the krama inggil lexicon by young generation based on education level as a form of implementation of subasita culture in Kudus. This study aims to describe the application of the krama inggil lexicon by today's younger generations, and to interpret the subasita culture that is reflected through the application of the krama inggil lexicon. This research is a qualitative descriptive study with a case study model. This study used 14 informants as data sources. The data of this research are in the form of informants' utterances which are indicated to contain the krama inggil lexicon. The technique of collecting data used observation techniques, listening proficiently, interviewing techniques, recording techniques, note taking techniques and questionnaire techniques. The data analysis technique used a qualitative descriptive technique. The results showed that: 1) the krama inggil lexicon was produced more by the younger generation with middle and lower education level; and 2) subasita culture is applied by the younger generation in different ways.

This is an open access article under the CC-BY-SA license.

\section{INFO ARTIKEL}

\section{Artikel histori}

Dikirim

Diperbaiki

Diterima

Kata kunci

Krama inggil

Leksikon

Subasita

Generasi muda

Tingkat pendidikan
Penelitian ini mengkaji tentang penerapan leksikon krama inggil oleh generasi muda berdasarkan tingkat pendidikan sebagai bentuk implementasi budaya subasita di Kudus. Penelitian ini bertujuan untuk mendeskripsikan penerapan leksikon krama inggil oleh generasi muda masa kini, dan menginterpretasi budaya subasita yang direfleksikan melalui penerapan leksikon krama inggil tersebut. Penelitian ini merupakan penelitian deskriptif kualitatif dengan model studi kasus. Penelitian ini menggunakan 14 orang informan sebagai sumber data. Data penelitian ini berupa ujaran informan yang terindikasi memuat leksikon krama inggil. Teknik pengumpulan data menggunakan teknik observasi, simak libat cakap, teknik wawancara, teknik rekam, teknik catat dan teknik kuesioner. Teknik analisis data menggunakan teknik deskriptif kualitatif. Hasil penelitian menunjukkan bahwa: 1) leksikon krama inggil lebih banyak diproduksi oleh generasi muda dengan tingkat pendidikan menengah kebawah; 2) budaya subasita diterapkan oleh generasi muda dengan cara yang berbeda-beda. 


\section{PENDAHULUAN}

Pada tatanan hubungan antar manusia, budaya nusantara menempatkan akhlak sebagai titik berat. Akhlak manusia sangat berkaitan dengan sikap, tingkah laku, termasuk bahasa yang digunakan manusia untuk saling berinteraksi. Sebagai makhluk sosial dan berbudaya, memang sudah seharusnya manusia memiliki norma sebagai pedoman interaksi terhadap sesama.

Berakaitan dengan akhlak, dalam budaya Jawa dikenal istilah tata krama. Secara harfiah tata krama berarti aturan dalam hubungan. Senada dengan itu, terdapat kata lain yang bermakna serupa namun tidak sama yaitu subasita. Berdasarkan kamus Baoesastra Djawa yang ditulis oleh Poerwadarminta dkk. (Poerwadarminta et al., 1939: 569) subasita adalah tata krama dalam pasrawungan 'berinteraksi dengan sesama'.

Masyarakat Jawa sangat erat kaitannya dengan subasita. Hal ini menandakan bahwa masyarakat Jawa memiliki pola pikir yang menitikberatkan sopan santun di atas segalanya. Masyarakat Jawa selalu menyampaikan segala hal dengan tertutup, halus, dan bermakna atau dalam budaya Jawa dikenal dengan istilah pasemon. Penerapan pasemon memiliki tujuan agar mitra tutur tidak tersinggung dengan komentar atau kritikan yang disampaikan penutur (Rahadini, 2020). Hal ini menunjukkan bahwa perilaku bahasa masyarakat Jawa cukup lemah lembut dan halus. Oleh karena itu dalam bahasa Jawa dikenal adanya ragam krama alus dan ngoko (kasar) sebagai salah satu praktik budaya subasita (Endraswara, 2012: 167).

Salah satu praktik subasita adalah penerapan unggah-ungguh basa. Kata unggah-ungguh sendiri menurut kamus Baoesastra Djawa adalah kaidah bahasa menurut kedudukannya (Poerwadarminta et al., 1939: 443) Dalam masyarakat Jawa, kedudukan menjadi hal penting yang mendasari pemilihan ragam bahasa yang akan digunakan untuk berinteraksi. Penggunaan leksikon krama inggil terhadap orang yang lebih tua/orang yang dihormati adalah contoh implementasi unggah-ungguh dalam berinteraksi dengan masyarakat.

Pada era ini, unggah-ungguh bukan lagi menjadi hal utama bagi sebagian remaja, bahkan remaja tidak tahu mengenai unggah-ungguh basa. Banyak faktor yang menyebabkan remaja kurang mengetahui budaya unggah-ungguh. Salah satunya yaitu faktor keluarga. Keluarga yang tidak membiasakan menerapkan unggah-ungguh membuat anak tidak mengerti tata krama dan prinsip kesopanan sesuai adat dan budaya Jawa (Effendi, 2015: 38; Ratnasari \& Jadmiko, 2018: 159).

Di samping itu, perubahan zaman yang tidak bisa dihindari menggeser nilai-nilai unggah-ungguh dalam kebudayaan Jawa. Hal ini dapat dilihat dari tutur bahasa generasi Jawa saat ini. Anak-anak muda zaman sekarang kurang produktif dalam menggunakan bahasa Jawa, utamanya dalam penggunaan ragam krama (Hayati, 2020). Kesalahan penggunaan ragam krama alus oleh generasi muda ini telah dibuktikan dalam penelitian Wibawa (2005: 153) dan Setyawan (2019: 153). Masing-masing penelitian tersebut menunjukkan bahwa generasi muda mulai dari tingkat sekolah menengah hingga mahasiswa kurang mampu menerapkan unggahungguh basa, dalam hal ini adalah penggunaan ragam krama alus.

Kesalahan penggunaan ragam krama alus oleh generasi muda zaman sekarang menunjukkan kurangnya pemerolehan leksikon krama inggil. Hal ini ditandai dengan terbatasnya ujaran yang menggunakan leksikon krama inggil terhadap orang tua, orang yang 


MIMESIS
UND. 2. No. 1, Januari 2021
Universitas
Ahmad Dahlan

dituakan atau orang yang dihormati. Fenomena ini dapat disebabkan oleh kurangnya penguasaan terhadap tingkat tutur bahasa Jawa, seperti yang telah diteliti oleh Romelah (Romelah, 2016: 274).

Berdasarkan hasil pengamatan, leksikon-leksikon krama inggil yang sering muncul dalam dialog sehari-hari misalnya adalah njenengan 'Anda' dan dhahar 'makan'. Bahkan sebagian anak muda dengan kelas sosial yang tinggi jarang menggunakan bahasa Jawa untuk berinteraksi dengan orang lain, sebagai gantinya adalah bahasa Indonesia. Fenomena terjadinya perbedaan penggunaan bahasa ini tercermin dalam penelitian yang dilakukan Ardiani (Ardiani, 2017). Penelitian tersebut menunjukkan adanya perbedaan penggunaan bahasa berdasarkan kelas sosialnya, yaitu berdasarkan profesi dan usia. Penelitian yang hampir sama juga membuktikan bahwa terjadi perbedaan penggunaan bahasa berdasarkan profesinya. Dalam penelitian Itaristansi (Itaristanti, 2012) menunjukkan adanya variasi bahasa yang digunakan oleh orang yang berprofesi sebagai sopir dan kondektur.

Dengan demikian, menarik jika diteliti seberapa jauh penggunaan leksikon krama inggil baik dalam percakapan sehari-hari oleh remaja masa kini berdasarkan kelas sosial, khususnya pada tingkat pendidikan, sebagai implementasi budaya subasita dalam masyarakat Jawa. Kelas sosial dijadikan variabel karena terdapat hipotesis yang menyatakan bahwa penggunaan bahasa oleh penutur akan berbeda-beda berdasarkan kelas sosialnya, mulai dari tingkat pendidikan, ekonomi, hingga profesi penutur. Hipotesis tersebut telah dibuktikan oleh Mallinson (Mallinson, 2007) dalam artikelnya yang berjudul "Social Class, Social Status and Stratification: Revisiting Familiar Concepts in Sociolinguistics". Hasil penelitian tersebut secara umum menyatakan bahwa terdapat perbedaan penggunaan bahasa Inggris pada perempuan dengan profesi dan tingkat pendidikan yang berbeda.

Sehubungan dengan hal itu, pada penelitian ini, peneliti bermaksud mengkaji bagaimana penerapan leksikon krama inggil oleh remaja masa kini berdasarkan tingkat pendidikannya dalam kehidupan sehari-hari, dan bagaimana budaya subasita direfleksikan dalam penerapan leksikon krama inggil tersebut. Dengan demikian tujuan penelitian ini adalah untuk mendeskripsikan penerapan leksikon krama inggil oleh remaja masa kini berdasarkan tingkat pendidikannya dalam kehidupan sehari-hari dan untuk mendeskripsikan budaya subasita yang direfleksikan dalam penerapan leksikon krama inggil tersebut.

\section{METODE}

Penelitian ini menggunakan pendekatan kualitatif dengan model studi kasus atau case study karena hanya menggunakan 14 orang subjek penelitian yang diambil menggunakan teknik purposive sampling. Penelitian studi kasus merupakan penelitian yang mendalami suatu kasus tertentu secara lebih mendalam (Raco \& Semiawan, 2010: 49).

Data penelitian ini adalah leksikon krama inggil yang ditemukan dalam ujaran informan dalam kehidupan sehari-sehari. Sehubungan dengan hal itu, sumber data penelitian ini adalah 14 informan yang memenuhi syarat: 1) generasi muda berusia 15-25 tahun; 2) berbahasa ibu bahasa Jawa; 3) berpendidikan tinggi atau berpendidikan rendah; 4) berdomisili di Desa 


MIMESIS
VOL. 2. No. 1, Januari 2021
Universitas
Ahmad Dahlan

Jepangpakis, Kudus, Jawa Tengah. Dengan demikian dapat diketahui lokasi penelitian ini terletak di Desa Jepangpakis, Kecamatan Jati, Kabupaten Kudus, Jawa Tengah.

Teknik pengumpulan data pada penelitian ini menggunakan teknik observasi, teknik simak libat cakap, teknik wawancara, teknik catat, teknik rekam, serta teknik kuesioner. Teknik pengumpulan data ini dilakukan dengan cara mengamati terlebih dahulu percakapan seharihari informan. Pengumpulan data lebih lanjut dilakukan pertama-tama menggunakan teknik kuesioner untuk melihat profil bahasa informan. Lebih lanjut, akan dilengkapi dengan teknik simak libat cakap dengan cara berpartisipasi dalam aktivitas berbahasa informan. Artinya, peneliti terlibat dalam percakapan informan sambil memperhatikan penggunaan bahasa informan (Mahsun, 2011: 93). Teknik simak libat cakap diteruskan dengan teknik wawancara untuk menggali informasi tentang preferensi penggunaan bahasa informan. Selanjutnya, untuk menghindari kehilangan data selama penelitian berlangsung, digunakan teknik rekam dan teknik catat.

Tenik analisis data pada penelitian ini menggunakan teknik deskriptif kualitatif. Validitas data didapatkan dengan ketekunan penelitian dan triangulasi sumber.

\section{PEMBAHASAN}

Berdasarkan hasil penelitian, terdapat perbedaan penggunaan bahasa oleh generasi muda dalam kehidupan sehari-hari dilihat dari tingkat pendidikan yang terjadi di Kudus. Hal ini sejalan dengan teori yang dikemukakan oleh Chaer dan Agustina yang menyatakan bahwa variasi bahasa dapat dilihat salah satunya dari kelompok sosial penuturnya yang disebut dengan sosiolek. Variasi bahasa sosiolek adalah variasi bahasa yang berkenaan dengan status, golongan, dan kelas sosial para penuturnya. Variasi bahasa ini menyangkut semua masalah pribadi para penuturnya, seperti usia, pendidikan, seks, pekerjaan, tingkat kebangsawanan, keadaan sosial ekonomi, dan lain sebagainya (Chaer \& Agustina, 2010: 64). Namun dalam penelitian ini, penanda kelas sosial dititikberatkan pada tingkat pendidikan saja.

Berdasarkan hasil analisis, tingkat pendidikan menengah ke bawah cenderung menggunakan bahasa Jawa sedangkan tingkat pendidikan menengah ke atas cenderung menggunakan bahasa Indonesia. Meskipun demikian orang-orang dengan tingkat pendidikan menengah ke atas masih menggunakan bahasa Jawa dalam beberapa situasi seperti berinteraksi terhadap orang tua kandung, kakak atau adik. Hal semacam ini berpengaruh pada cara penerapan budaya Subasita sebagai identitas masyarakat Jawa. Untuk lebih rinci dapat diuraikan sebagai berikut.

\section{Bahasa dan Tingkat Pendidikan Informan}

Dalam penelitian ini, informan akan diklasifikasikan berdasarkan kelas sosial, yaitu kelas menengah ke bawah dan kelas menengah ke atas. Kategori kelas tersebut ditentukan dari tingkat pendidikan informan. Hal ini didasarkan pada teori yang menyatakan bahwa perbedaan tingkat pendidikan juga akan menghasilkan variasi bahasa. Orang yang berpendidikan tinggi berbeda variasi bahasa yang digunakan dengan orang yang berpendidikan rendah apalagi orang tersebut tidak berpendidikan (pendidikan akademik). Perbedaan ini terutama terlihat pada 


MIMESIS
VOL. 2. No. 1, Januari 2021
Universitas
Ahmad Dahlan

penggunaan struktur dan pilihan kosakata yang digunakannya pada waktu berinteraksi (Chaer \& Agustina, 2010: 65).

Berdasarkan hasil kuesioner yang disebarkan kepada 14 informan di Desa Jepangpakis, informan dengan kelas sosial menengah ke bawah adalah informan dengan tingkat pendidikan tertinggi SMA sedangkan informan dengan kelas sosial menengah ke atas adalah informan yang tingkat pendidikan terendah adalah Sarjana. Berdasarkan hasil analisis, masing-masing informan yang termasuk ke dalam masing-masing kelas memiliki perbedaan pemakaian bahasa dalam berinteraksi dengan keluarga dan orang-orang di sekitarnya.

\section{a. Informan dengan Tingkat Pendidikan Menengah ke Bawah}

Berdasarkan hasil kuesioner, informan dengan tingkat pendidikan menengah ke bawah, terdiri dari informan dengan lulusan SMP dan SMA. Profesi informan mulai dari ibu rumah tangga, karyawan toko, hingga buruh pabrik. Berdasarkan hasil analisis kebahasaan, informan dengan kelas menengah ke bawah ini memiliki preferensial menggunakan bahasa Jawa dalam berinteraksi sehari-hari, baik dengan orang tua kandung, saudara, orang yang lebih tua, maupun teman sebaya. Ragam bahasa Jawa yang digunakan oleh informan adalah ragam ngoko lugu, ngoko alus, dan krama alus. Meskipun demikian, orang-orang dengan kelas tersebut masih menggunakan bahasa Indonesia dalam beberapa situasi tutur, seperti berkomunikasi dengan orang asing yang tidak bisa berbahasa Jawa dan berinteraksi dengan anak-anak.

\section{b. Informan dengan Tingkat Pendidikan Menengah ke Atas}

Berdasarkan hasil kuesioner, informan dengan tingkat pendidikan menengah ke atas terdiri dari informan dengan tingkat pendidikan sarjana dan pascasarjana. Masing-masing informan berprofesi mulai dari mahasiswa, guru, dosen, hingga karyawan perusahaan besar seperti Telkomsel, Indosat, dan Pura. Berdasarkan hasil penelitian kebahasaan, informan dengan kelas ini memiliki preferensial menggunakan bahasa Indonesia dan bahasa Jawa dalam berinteraksi sehari-hari. Penggunaan kedua bahasa ini dilakukan dengan cara campur kode. Berdasarkan hasil penelitian, kata dalam bahasa Indonesia lebih sering muncul dibandingkan dengan bahasa Jawa walaupun mitra tutur menggunakan bahasa Jawa untuk berinteraksi. Hal ini disebabkan penutur merasa lebih nyaman menggunakan bahasa Indonesia. Meskipun demikian, dalam beberapa situasi tutur, informan menggunakan bahasa Jawa, seperti ketika berinteraksi dengan orang tua kandung, nenek/kakek, adik/kakak, dan teman sebaya. Ragam bahasa Jawa yang digunakan oleh informan dalam kelas sosial ini adalah ragam ngoko lugu.

\section{Penerapan Leksikon Krama Inggil}

Berdasarkan hasil penelitian, baik informan yang berada pada tingkat pendidikan menengah ke bawah maupun menengah ke atas mampu memproduksi ujaran bahasa Jawa dengan leksikon krama inggil di dalamnya namun dengan jumlah yang sangat berbeda. Jumlah ujaran menggunakan leksikon krama inggil oleh informan dengan kelas menengah ke bawah lebih banyak dibandingkan dengan informan dengan kelas menengah ke atas. Berdasarkan hasil wawancara, para informan dengan kelas menengah ke atas mengaku mengetahui leksikonleksikon krama inggil namun tidak pernah menggunakannya, atau jarang menggunakannya. 


MIMESIS
Universitas
Ahmad Dahlan
VOL. 2. No. 1, Januari 2021

Hal ini disebabkan oleh informan dengan kelas menengah ke atas lebih sering menggunakan bahasa Indonesia untuk berinteraksi baik di dunia kerja maupun di dunia pendidikan. Penerapan leksikon krama inggil oleh informan berdasarkan tingkat pendidikannya adalah sebagai berikut.

\section{a. Penerapan oleh Generasi Muda dengan Tingkat Pendidikan Menengah ke Bawah}

Berdasarkan hasil analisis, penerapan leksikon krama inggil oleh informan dengan tingkat pendidikan menengah ke bawah dikategorikan menjadi penerapan dalam interaksi terhadap orang dengan tingkat keakraban rendah, dan interaksi terhadap orang dengan tingkat keakraban tinggi.

\section{1) Interaksi terhadap Orang dengan Tingkat Keakraban Rendah}

Berdasarkan hasil penelitian, penerapan leksikon krama inggil oleh informan paling banyak ditemukan untuk berinteraksi dengan saudara maupun orang lain dengan tingkat keakraban rendah seperti tetangga, baru dikenal, dan orang asing. Berdasarkan hasil pengamatan dan wawancara leksikon-leksikon krama inggil yang sering digunakan dalam percakapan adalah sebagai berikut.

Tabel 1. Leksikon Krama Inggil yang Sering Digunakan

\begin{tabular}{|l|l|}
\hline \multicolumn{1}{|c|}{ Krama Inggil } & Bahasa Indonesia \\
\hline pinarak & duduk \\
\hline kersa & mau \\
\hline dalem & saya \\
\hline siram & mandi \\
\hline kagungan & mempunyai \\
\hline asma & nama \\
\hline panjenengan & kamu \\
\hline gerah & sakit \\
\hline tindak & pergi \\
\hline ngasta & mengajar \\
\hline kondur & pulang \\
\hline mirsani & melihat \\
\hline dalem & rumah \\
\hline dhahar & makan \\
\hline ngampil & meminjam \\
\hline mundhut & membeli \\
\hline nitih & naik \\
\hline sare & tidur \\
\hline sugeng & hidup \\
\hline dherek & ikut \\
\hline rawuh & datang \\
\hline agem & pakai \\
\hline garwa & istri/suami \\
\hline nyuwun & minta \\
\hline paningal & mata \\
\hline seda & meninggal dunia \\
\hline rema/rikma & rambut \\
\hline & \\
\hline
\end{tabular}




MIMESIS
Universitas
Ahmad Dahlan
VOL. 2. No. 1, Januari 2021

\begin{tabular}{|l|l|}
\hline yuswa & umur \\
\hline waja & gigi \\
\hline wijik & membasuh tangan \\
\hline
\end{tabular}

Tabel tersebut menunjukkan leksikon-leksikon yang sering digunakan oleh para informan dalam percakapan sehari-hari dengan tetangga, saudara, orang lain, dan teman yang memiliki tingkat keakraban kurang atau rendah. Berdasarkan hasil analisis, leksikon-leksikon krama inggil tersebut diterapkan dalam bahasa Jawa ragam ngoko alus dan krama alus. Namun, penggunaan ragam tersebut dibedakan berdasarkan usia mitra tutur informan. Para informan cenderung menggunakan ragam krama alus ketika berinteraksi dengan orang yang jauh lebih tua, seperti yang terdapat pada contoh berikut.

Data 1

KONTEKS: Informan (Hanif) dimintai tolong oleh tetangga yang usianya jauh lebih tua.

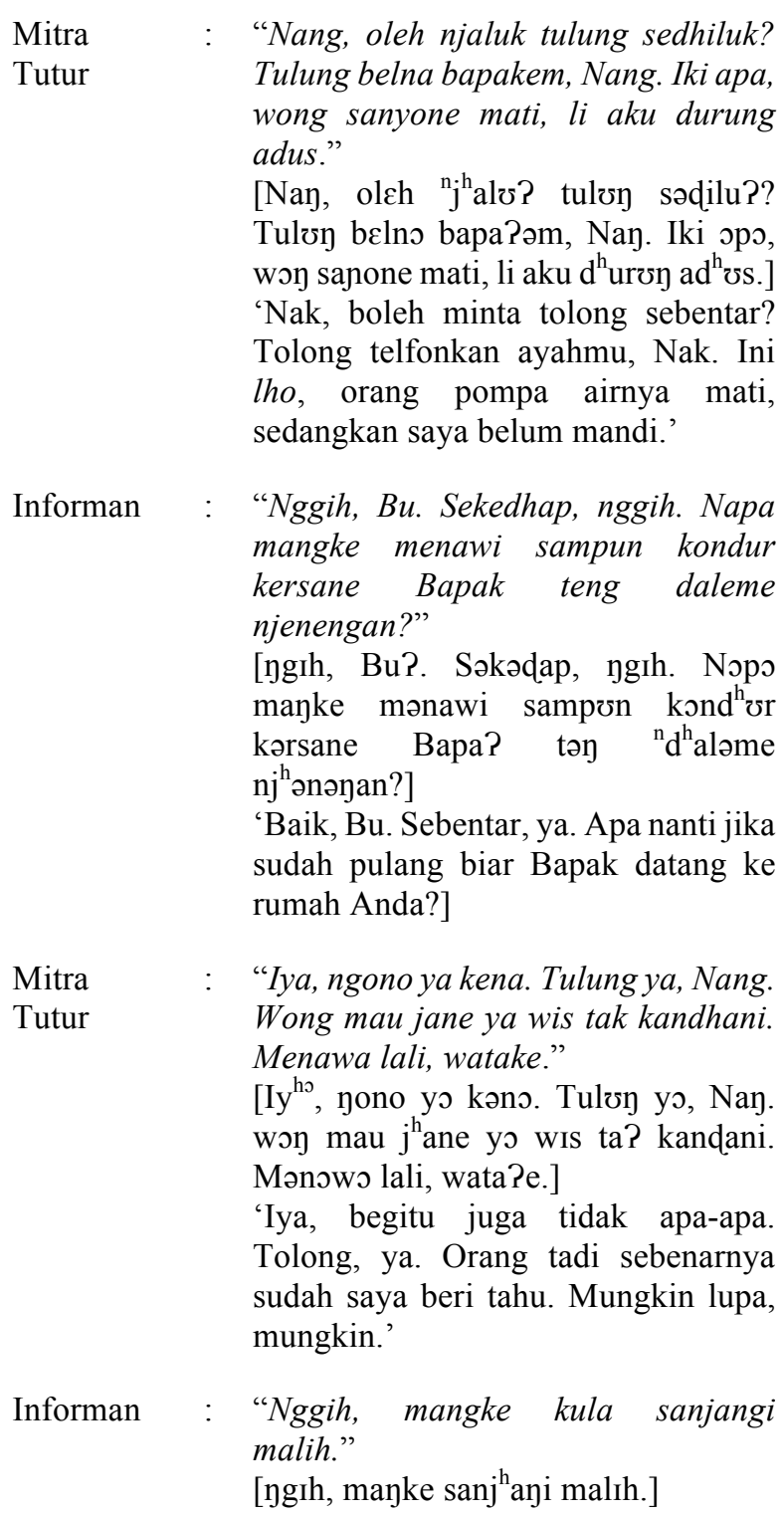




MIMESIS
Universitas
Ahmad Dahlan

'Iya, nanti saya beri tahu lagi.'

Berdasarkan contoh data tersebut, dapat diketahui penggunaan ragam krama alus yang ditandai dengan penggunaan leksikon krama dan krama inggil dalam seluruh ujaran informan. Namun, dalam data tersebut tampak bahwa informan masih menggunakan afiks ngoko -e dan -ne yang mana dalam kaidah pembentukan ragam krama alus afiks tersebut harus diganti dengan -ipun. Berdasarkan hasil wawancara, informan tidak terbiasa menggunakan afiks -ipun untuk berinteraksi dengan siapapun. Para informan terbiasa menggunakan afiks ngoko seperti $-e$, -ne, dan -ke. Hal ini dikarenakan seluruh infoman dalam kelas menengah ke bawah lebih sering berinteraksi dengan orang-orang dengan tingkat keakraban tinggi, sehingga penggunaan ragam ngoko dalam percakapan sehari-hari lebih tinggi.

Selain ragam krama alus, para informan juga menerapkan leksikon krama inggil dalam ragam ngoko alus. Ragam ini digunakan oleh informan untuk berkomunikasi dengan orang yang tingkat keakrabannya rendah dan memiliki keterpautan usia yang tidak jauh. Penerapan leksikon krama inggil dalam ragam ngoko alus seperti yang terdapat pada contoh data berikut ini.

Data 2

KONTEKS: Informan (Umi) membeli sesuatu di warung tetangga.

\begin{tabular}{|c|c|c|}
\hline Informan & : & $\begin{array}{l}\text { "Mbak, tumbas uyah kalih niku, } \\
\text { napa, es lilin." } \\
{\left[\mathrm{Mb}^{\mathrm{h}} \text { a?, tumb as uyah kalıh niku, }\right.} \\
\text { nopo, es lilin.] } \\
\text { 'Mbak, beli garam dan itu, apa sih, } \\
\text { es lilin.' }\end{array}$ \\
\hline Mitra tutur & : & $\begin{array}{l}\text { “Ese sing apa iki, Mi?” } \\
\text { [Ese sin opo iki, Mi?] } \\
\text { 'Esnya yang rasa apa ini, Mi?' }\end{array}$ \\
\hline Informan & : & $\begin{array}{l}\text { “Wontene apa wae, Mbak?” } \\
\text { [Wontəne spo whae, Mb }{ }^{\mathrm{h}} \mathrm{a} \text { ?] } \\
\text { "Adanya apa aja, Mbak?' }\end{array}$ \\
\hline $\begin{array}{l}\text { Mitra } \\
\text { Tutur }\end{array}$ & : & 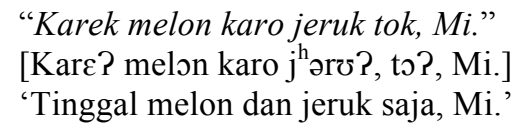 \\
\hline Informan & : & $\begin{array}{l}\text { "Nggih, melon wae, Mbak." } \\
\left.\text { [ygih, melon whae, Mb }{ }^{\mathrm{h}} \mathrm{a} .\right] \\
\text { 'Ya, melon saja, Mbak.' }\end{array}$ \\
\hline $\begin{array}{l}\text { Mitra } \\
\text { Tutur }\end{array}$ & : & $\begin{array}{l}\text { "Wis, apa meneh?” } \\
\text { [Wis, opo mənch?] } \\
\text { 'Sudah, apa lagi?' }\end{array}$ \\
\hline Informan & $:$ & $\begin{array}{l}\text { "Kuwi, Mbak, mihun. Aku ora gadug } \\
\text { kok. Tulung pundhutke, Mbak, } \\
\text { njenengan sing dhuwur. Hehehe" } \\
\text { [Kuwi, Mbha?, mihun. Aku ora } \\
\text { g }^{\mathrm{h}} \mathrm{ad}^{\mathrm{h}} \text { } \mathrm{g} \text { kə?. Tuløy pundrtke, }\end{array}$ \\
\hline
\end{tabular}




MIMESIS
Universitas
Ahmad Dahlan
VOL. 2. No. 1, Januari 2021

Mb ${ }^{\mathrm{h}} \mathrm{a}$, nj ${ }^{\mathrm{h}}$ ənəyan sin duwør.
Hehehe]
'Itu, Mbak, bihun. Tangan saya
tidak sampai kok. Minta tolong
ambilkan, Mbak, Anda yang
badannya tinggi. Hehehe'

Berdasarkan contoh data tersebut, dapat diketahui bahwa informan menggunakan ragam ngoko alus untuk berinteraksi dengan orang lain dengan tingkat keakraban rendah. Hal ini ditandai dengan digunakannya leksikon-leksikon ngoko namun dalam beberapa hal digunakan leksikon krama inggil seperti njenengan 'Anda' dan pundhutke 'ambilkan', pada ujaran ke-10, yang mana leksikon tersebut mengacu pada mitra tuturnya. Penggunaan ragam ngoko alus ini digunakan informan karena berkomunikasi dengan orang yang dikenal namun tidak akrab, sehingga ada usaha untuk menghormati mitra tutur.

\section{2) Interaksi terhadap Orang dengan Tingkat Keakraban Tinggi}

Berdasarkan hasil penelitian, penerapan leksikon krama inggil oleh informan untuk berinteraksi dengan orang yang tingkat keakrabannya tinggi tidak banyak ditemukan. Hal ini dikarenakan para informan lebih sering menggunakan ragam ngoko lugu. Meskipun demikian, pada beberapa informan dengan kelas menengah ke bawah ini masih ditemukan leksikon krama inggil namun dengan jumlah yang sangat terbatas seperti yang terdapat pada tabel berikut ini.

Tabel 2. Leksikon Krama Inggil terhadap Orang yang Akrab

\begin{tabular}{|l|l|}
\hline \multicolumn{1}{|c|}{ Krama Inggil } & \multicolumn{1}{c|}{ Bahasa Indonesia } \\
\hline dhahar & makan \\
\hline panjenengan & kamu \\
\hline dalem & saya \\
\hline
\end{tabular}

Berdasarkan hasil analisis, leksikon krama inggil diterapkan oleh informan dalam ragam ngoko alus untuk berinteraksi dengan orang yang jauh lebih tua seperti orang tua kandung serta nenek/kakek. Sementara itu, untuk berinteraksi dengan orang yang tingkat keakrabannya tinggi namun terpaut usia yang tidak jauh, informan akan menggunakan ragam ngoko lugu, sehingga tidak ditemukan leksikon krama inggil di dalam ujarannya. Hal ini sejalan dengan penelitian Iriansyah (Rinzat Iriyansah, 2019: 80) yang menyatakan bahwa keakraban penutur dan mitra tutur mempengaruhi ragam bahasa yang digunakan. Penelitian tersebut menunjukkan bahwa semakin akrab peserta tutur, semakin santai ragam yang digunakan, dalam hal ini adalah ragam ngoko 


MIMESIS
VOL. 2. No. 1, Januari 2021
Universitas
Ahmad Dahlan

\section{b. Penerapan oleh Generasi Muda dengan Tingkat Pendidikan Menengah ke Atas}

Berdasarkan hasil analisis, penerapan leksikon krama inggil oleh informan dengan tingkat pendidikan menengah ke atas dikategorikan menjadi penerapan dalam interaksi terhadap orang dengan tingkat keakraban rendah, dan interaksi terhadap orang dengan tingkat keakraban tinggi.

\section{1) Interaksi terhadap Orang dengan Tingkat Keakraban Rendah}

Berdasarkan hasil penelitian, informan dengan kelas menengah ke atas ini cenderung menggunakan bahasa Indonesia untuk berinteraksi dengan orang yang tingkat keakrabannya rendah. Meskipun demikian leksikon krama inggil masih digunakan dalam upaya menghormati mitra tutur. Penggunaan leksikon krama inggil dalam ujaran informan dengan kelas ini diterapkan dengan cara campur kode (code mixing). Leksikon krama inggil yang sering muncul dalam ujaran para informan adalah njenengan 'Anda' dan dalem 'saya'. Meskipun dapat dikatakan sangat terbatas, informan mengaku mengetahui leksikon-leksikon krama inggil hanya saja jarang bahkan tidak pernah memproduksinya dalam ujaran sehari-hari. Hal ini dikarenakan informan lebih sering berada pada lingkungan yang menggunakan bahasa Indonesia sebagai bahasa dalam berinteraksi seperti di lingkungan kerja dan lingkungan pendidikan. Dengan demikian produksi ujaran menggunakan leksikon krama inggil sangat terbatas. Penggunaan leksikon krama inggil oleh informan dengan kelas sosial menengah ke atas adalah sebagai beirkut.

\section{Data 3}

KONTEKS: Informan (Azza) disapa oleh tetangganya ketika sedang berada di teras rumahnya.

\begin{tabular}{|c|c|c|}
\hline Mitra tutur & : & $\begin{array}{l}\text { "Lho, Mbak Asa ning omah, ta?" } \\
\text { [Lho, Mb a? Asa niy omah, to?] } \\
\text { 'Lho, Mbak Asa di rumah, to?' }\end{array}$ \\
\hline Informan & : & $\begin{array}{l}\text { "Iya, Bu Ru. Kuliahnya daring, } \\
\text { soalnya. Jadi di rumah." } \\
\text { [Iya, Bu? Ru. Kuliahna darin, } \\
\text { soalna. Jadi di rumah.] } \\
\text { 'Iya, Bu Ru. Kuliahnya daring, } \\
\text { soalnya. Jadi di rumah.' }\end{array}$ \\
\hline $\begin{array}{l}\text { Mitra } \\
\text { Tutur }\end{array}$ & : & $\begin{array}{l}\text { "Lho, Dea kok ijih ning Semarang? } \\
\text { Jare ijih kuliah." } \\
\text { [Lho, dea ko? ij }{ }^{\mathrm{h}} \varepsilon \mathrm{h} \text { nin Somaray? } \\
\mathrm{J}^{\mathrm{h}} \text { are ij } \mathrm{ij} \text { kuliah.] } \\
\text { 'Lho, Dea kok masih di Semarang? } \\
\text { Katanya masih (ada) kuliah.' }\end{array}$ \\
\hline Informan & & $\begin{array}{l}\text { "Lho, Mbak Dea kemarin kayanya } \\
\text { bilang mau pulang. Tak ajak bareng } \\
\text { ndak mau katanya. Ndak bilang } \\
\text { kalih njenengan, ta, Bu?" } \\
\text { [Lho, Mb }{ }^{\mathrm{h}} \text { a? dea kəmarin kaya?na } \\
\mathrm{b}^{\mathrm{h}} \text { ilay mau pulay. Ta? aja }{ }^{\mathrm{h}} \text { ? barəy } \\
\text { nda? mau katana. nda? b } \mathrm{b}^{\mathrm{h}} \text { ilay kalıh } \\
\mathrm{nj}^{\mathrm{h}} \text { ənəyan, to, Bu??] }\end{array}$ \\
\hline
\end{tabular}




MIMESIS
Universitas
Ahmad Dahlan
VOL. 2. No. 1, Januari 2021

\footnotetext{
'Lho, Mbak Dea kemarin kayanya bilang akan pulang. Saya ajak (pulang) bareng tidak mau katanya. Tidak bilang kepada Anda, ta, Bu?'
}

Berdasarkan contoh data tersebut, tampak bahwa informan menggunakan bahasa Indonesia walupun mitra tutur menggunakan bahasa Jawa. Meskipun demikian, sebagai upaya menghormati mitra tutur, informan mengganti kata 'anda/kamu' dalam bahasa Indonesia menjadi njenengan 'Anda' dalam bahasa Jawa. Hal ini menunjukkan bahwa informan mengetahui jika kata kamu dalam bahasa Indonesia atau kata kowe 'kamu' dalam bahasa Jawa tidak pantas diucapkan terhadap orang yang lebih tua, sehingga informan menggantinya dengan njenengan 'Anda' dalam krama inggil. Artinya, informan memahami tata krama dan unggah-ungguh dalam budaya Jawa.

\section{2) Interaksi terhadap Orang dengan Tingkat Keakraban Tinggi}

Berdasarkan hasil penelitian, bahasa yang digunakan informan dengan tingkat pendidikan menengah ke atas untuk berinteraksi terhadap orang yang tingkat keakrabannya tinggi adalah bahasa Jawa ragam ngoko lugu dan bahasa Indonesia. Kedua bahasa tersebut digunakan dengan cara campur kode (code mixing).

Berdasarkan hasil pengamatan, tidak ditemukan leksikon krama inggil dalam percakapan informan dengan orang yang tingkat keakrabannya tinggi seperti orang tua kandung, saudara kandung, nenek/kakek. Hal ini dikarenakan informan tidak terbiasa menggunakan leksikonleksikon krama maupun krama inggil. Seperti yang terdapat pada contoh data berikut ini.

Data 4

KONTEKS: Rumah informan (Sheva) kedatangan tamu ketika informan sedang berbicara dengan temannya.

\begin{tabular}{|c|c|c|}
\hline Informan & : & $\begin{array}{l}\text { "Mah, ini lho ada tamu. Masuk dulu, } \\
\text { Tante. Mbak ngaleh njero, yuk?" } \\
\text { [Mah, ini lho ada tamu. Masซ? dulu, } \\
\text { Tantə. Mb }{ }^{\mathrm{h}} \text { a?, yaleh nj }{ }^{\mathrm{h}} \text { əro, yซ??] }\end{array}$ \\
\hline $\begin{array}{l}\text { Mitra } \\
\text { Tutur }\end{array}$ & : & $\begin{array}{l}\text { "Sapa, ta? Ngono ku leh dikon } \\
\text { masuk dhisik." } \\
\text { [Sopo, to? yono ku leh dikon masø? } \\
\text { ndisı?. ] }\end{array}$ \\
\hline Informan & : & $\begin{array}{l}\text { "Lho, wong tadi wis tak suruh } \\
\text { masuk kok. Mamah re suwene pol } \\
\text { rak metu-metu kok, tak tinggal } \\
\text { masuk ah. Gage tah metu sik ngono } \\
\text { ku." } \\
\text { [Lho, woy tadi wis ta? suruh masø? } \\
\text { ko?. Mamah } \mathrm{r}^{\mathrm{h}} \text { e suwene pol ra? } \\
\text { mətu- motu ko?, ta? tingal masø? } \\
\text { ah. } \mathrm{G}^{\mathrm{h}} \mathrm{ag}^{\mathrm{g}} \mathrm{e} \text { tah motu si? yono ku.] }\end{array}$ \\
\hline
\end{tabular}




MIMESIS
Universitas
Ahmad Dahlan

\begin{tabular}{|c|c|c|}
\hline & & $\begin{array}{l}\text { 'Lho, orang tadi sudah saya suruh } \\
\text { masuk kok. Mama aja lama sekali } \\
\text { tidak keluar-keluar, saya tinggal } \\
\text { masuk ah. Cepatlah keluar dulu } \\
\text { begitu.' }\end{array}$ \\
\hline $\begin{array}{l}\text { Mitra } \\
\text { Tutur } 1\end{array}$ & : & $\begin{array}{l}\text { "Mamah rung salin ngene kok. } \\
\text { Angger kuwe tah metu sedhela, kon } \\
\text { mlebu." } \\
\text { [Mamah ron salın yene ko?. Aygər } \\
\text { kuwe tah mətu sədelə?, kən } \\
\text { mləb } \\
\text { 'Mama belum ganti baju gini kok. } \\
\text { Kamu saja yang keluar, suruh } \\
\text { masuk.' }\end{array}$ \\
\hline Informan & : & $\begin{array}{l}\text { "Emoh, bajuku ngene kok. Pah, } \\
\text { Papah wae, Pah. Aku ngenenan } \\
\text { kok." } \\
\text { [əmoh, b }{ }^{\mathrm{h}} \text { aj } \mathrm{h} \text { ?ku yene ko?. Pah, } \\
\text { Papah w }{ }^{\mathrm{h}} \mathrm{ae}, \text { Pah. Aku yenenan } \\
\text { ko?.] } \\
\text { 'Tidak mau, bajuku seperti ini kok. } \\
\text { Pah, Papah saja, Pah. (baju) Aku } \\
\text { seperti ini kok.' }\end{array}$ \\
\hline $\begin{array}{l}\text { Mitra tutur } \\
2\end{array}$ & & $\begin{array}{l}\text { "Sapa, sih? Owalah, mangga, Bu, } \\
\text { pinarak mriki, ah." } \\
\text { [Sopo, sih? Owalah, mongo, Bu, } \\
\text { pinara? mriki, ah.] } \\
\text { 'Siapa, sih? Oh, silakan, Bu, duduk } \\
\text { sini.' }\end{array}$ \\
\hline
\end{tabular}

Pada contoh data tersebut dapat diketahui bahwa terjadi campur kode antara bahasa Indonesia dan bahasa Jawa ragam ngoko. Dialog tersebut menunjukkan adanya interferensi bahasa Indonesia ke dalam bahasa Jawa. Hal ini disebabkan oleh bilingualisme penuturnya yang mengakibatkan terjadinya kontak bahasa antara bahasa Jawa dan bahasa Indonesia. Hal ini seperti yang dijelaskan dalam penelitian Hidayat dan Setiawan (Hidayat \& Setiawan, 2015: 165) bahwa terjadinya interferensi bahasa salah satunya disebabkan oleh kontak bahasa sebagai akibat bilingualisme penuturnya.

Berdasarkan hasil analisis, tidak ditemukan leksikon krama inggil dalam tuturan dengan orang yang tingkat keakrabannya tinggi. Hal ini dikarenakan kedekatan yang dimiliki informan dan mitra tuturnya menempatkan keduanya dalam posisi sebagai teman, sehingga tidak ada upaya saling menghormati. Seperti penelitian sebelumnya yang mengemukakan bahwa tuturan masyarakat Jawa didasarkan pada parameter pragmatik, salah satunya yaitu jauh-dekatnya hubungan penutur dan mitra tutur (Tobing, 2015). Meskipun demikian berdasarkan data tersebut, informan cenderung menghindari bahasa Jawa yang terkesan kasar untuk diucapkan terhadap orang tua seperti leksikon kowe 'Anda'. Pada data tersebut dapat dilihat bahwa informan mengganti pronomina persona orang kedua dengan kata sapaan mamah atau papah. 
Dengan demikian dapat diketahui bahwa informan secara tidak langsung memahami tata krama dan unggah-ungguh basa dalam budaya Jawa.

\section{Implementasi budaya Subasita melalui penggunaan leksikon krama Inggil}

Perkembangan zaman dan teknologi secara kontinyu menggeser budaya unggah-ungguh basa dalam masyarakat Jawa, terutama pada generasi muda. Bahasa Jawa menurut generasi muda adalah budaya yang telah ketinggalan zaman, tidak penting, dan tidak menunjukkan prestise. Hal ini dibuktikan dengan nilai-nilai akademik generasi muda pada bidang bahasa Inggris dan bahasa Indonesia lebih tinggi dibandingkan dengan bahasa pertamanya, yaitu bahasa Jawa.

Berdasarkan hasil penelitian, budaya subasita yang tercermin dari penerapan unggahungguh oleh generasi muda masa kini, salah satunya dengan indikator penggunaan leksikon krama inggil, berbeda-beda berdasarkan tingkat pendidikannya. Semakin tinggi pendidikan seseorang, maka penggunaan leksikon krama inggil akan semakin rendah. Begitu juga sebaliknya. Hal ini sejalan dengan penelitian Sarah Spencer dkk. (Spencer et al., 2013: 133) yang menyatakan bahwa individu atau kelompok akan menggunakan bahasa yang berbeda sesuai identitas diri atau kelompoknya. Penggunaan bahasa yang berbeda ini berhubungan dengan kelas sosial penuturnya, termasuk di dalamnya adalah tingkat pendidikan penutur. Secara lebih rinci, perbedaan ini disebabkan oleh lingkungan yang berbeda pada tiap-tiap generasi muda sesuai dengan tingkat pendidikan, bahan bacaan, lingkungan kerja, dan lain sebagainya.

Meskipun demikian, berdasarkan hasil penelitian, generasi muda pada masin-masing tingkat menerapkan budaya subasita dengan cara yang berbeda. Generasi muda pada tingkat pendidikan menengah ke bawah menerapkan budaya subasita melalui penggunaan bahasa Jawa ragam ngoko alus, krama lugu, dan krama alus yang mana pada masing-asing ragam mengindikasikan bentuk penghormatan terhadap mitra tutur, sedangkan generasi muda pada tingkat pendidikan menengah ke atas menerapkan budaya subasita melalui penggunaan bahasa Indonesia yang baik dan sopan, serta penggunaan leksikon krama inggil untuk menggantikan pronomina persona orang ke dua seperti kata kowe 'Anda' yang digantikan dengan njenengan 'Anda'.

Selain itu, terdapat kemiripan dalam penerapan budaya subasita terhadap orang tua kandung. Baik generasi muda dengan tingkat pendidikan menengah ke bawah maupun menengah ke atas, tidak menerapkan budaya subasita dengan baik terhadap orang tua kandung. Generasi muda memiliki preferensi menggunakan bahasa Jawa ragam ngoko atau campuran antara bahasa Indonesia dan bahasa Jawa ngoko untuk berkomunikasi dengan orang tua kandung. Padahal, dalam budaya subasita sudah seharusnya yang muda menghormati yang lebih tua salah satunya melalui pemilihan ragam bahasa.

Tidak seperti ketika berinteraksi dengan orang yang tingkat keakrabannya rendah, dalam ujaran generasi muda dengan tingkat pendidikan menengah ke bawah terhadap orang tua kandung, jarang ditemukan penggunaan leksikon krama inggil. Penggunaan leksikon krama inggil ini terbatas pada pengubahan pronomina persona orang kedua njenengan 'Anda'. Dengan kasus yang sama, pada generasi muda dengan tingkat pendidikan menengah ke atas sama sekali tidak dijumpai leksikon krama inggil, namun penerapan budaya subasita pada 
tingkat ini tampak pada penghindaran penggunaan pronomina persona orang kedua dalam bahasa Jawa kasar seperti kowe 'Anda' yang mana diganti dengan kata sapaan seperti Ibu, Mama, Papa, Mbak, dsb.

\section{KESIMPULAN}

Berdasarkan hasil penelitian, dapat disimpulkan bahwa penerapan leksikon krama inggil oleh generasi muda berbeda-beda berdasarkan tingkat pendidikannya. Semakin rendah tingkat pendidikan seseorang, maka semakin banyak leksikon krama inggil yang diproduksi. Sebaliknya, semakin tinggi tingkat pendidikan seseorang, semakin sedikit leksikon krama inggil yang diproduksi. Meskipun terdapat perbedaan pada kuantitas produksi leksikon krama inggil, generasi muda masa kini tetap mengimplementasikan budaya subasita, namun dengan cara yang berbeda. Generasi muda dengan tingkat pendidikan menengah ke bawah mengimplementasikan budaya subasita melalui tuturan bahasa Jawa ragam ngoko alus, krama, dan krama alus. Sedangkan pada generasi muda dengan tingkat pendidikan menengah ke atas mengimplementasikan budaya subasita melalui tuturan berbahasa Indonesia yang baik dan sopan, serta tuturan bahasa Jawa dengan menghindari kata yang berkonotasi kasar.

\section{DAFTAR PUSTAKA}

Ardiani, W. M. (2017). Penggunaan Bahasa Berdasarkan Stratifikasi Sosial Di Puskesmas Kabupaten Sidoarjo: Kajian Siolinguistik. Skriptorium, 6(2).

Chaer, A., \& Agustina, L. (2010). Sosiolinguistik: Perkenalan Awal. Rineka Cipta.

Effendi, K. (2015). Kepemimpinan Orangtua dalam Mendidik Anak Melalui Unggah-ungguh Basa dan Basa Semu di Lingkungan Masyarakat. PSIKOPEDAGOGIA Jurnal Bimbingan Dan Konseling, 4(1), 31. https://doi.org/10.12928/psikopedagogia.v4i1.4490

Endraswara, S. (2012). Ilmu Jiwa Jawa. Narasi.

Hayati, I. U. (2020). Unggah Ungguh dalam Bahasa Jawa yang Kian Terlupa. Etnis. https://etnis.id/unggah-ungguh-dalam-bahasa-jawa-yang-kian-terlupa/

Hidayat, R., \& Setiawan, T. (2015). Interferensi Bahasa Jawa Ke Dalam Bahasa Indonesia Pada Keterampilan Berbicara Siswa Negeri 1 Pleret, Bantul. LingTera, 2(2), 156. https://doi.org/10.21831/lt.v2i2.7374

Itaristanti. (2012). Bahasa Dan Kelas Sosial : Studi Kasus Variasi Bahasa Sopir Dan Kondektur Angkutan Kota Di Yogyakarta. Edueksos, 1(Jurnal Edueksos Vol I No 1, Januari-Juni 2012), 127. https://doi.org/10.24235/edueksos.v1i1.620

Mahsun. (2011). Metode Penelitian Bahasa: Tahapan Strategi, Metode, dan Tekniknya (Edisi Revi). RajaGrafindo Persada.

Mallinson, C. (2007). Social class, social status and stratification: Revisiting familiar concepts in sociolinguistics. University of Pennsylvania Working Papers in Linguistics: Selected Papers from NWAV 35, 13(2), 149-163. https://repository.upenn.edu/cgi/viewcontent.cgi?article=1010\&context=pwpl

Poerwadarminta, W. J. S., Hardjasoedarmo, C. S., \& Poedjasoedira, J. C. (1939). Baoesastra Djawa. J. B. Wolters`Uitgevers Maatschappij N. V.

Raco, J. R., \& Semiawan, C. R. (2010). Metode Penelitian Kualitatif: Jenis, Karakteristik, dan 


MIMESIS
Universitas
Ahmad Dahlan
VOL. 2. No. 1, Januari 2021

Keunggulannya. Grasindo.

Rahadini, A. A. (2020). Pasemon: Wujud Keeleganan Tuturan Direktif Masyarakat. Mimesis, I(1). https://doi.org/http://dx.doi.org/10.12928/mms.v1i1.1641

Ratnasari, K. N., \& Jadmiko, R. S. (2018). Analysis of Use of Krama Inggil Languages From Parents on The Value of Children Charges in Ariyojeding Village Rejotangan Tulungagung. Jurnal Pendidikan Karakter, 2, 152-160. https://doi.org/10.21831/jpk.v8i2.20292

Rinzat Iriyansah, M. (2019). Ngoko and Krama in Non Formal Diglosia Situation in Lamongan (A Sociolinguistic Study). Jurnal $\quad$ KATA, 36. https://doi.org/10.22216/kata.v3i1.3954

Romelah. (2016). Kekacauan Tingkat Tutur Bahasa Jawa di Lingkungan Kabupaten Kebumen Jawa Tengah. Lingua, 13(2), 1689-1699. https://doi.org/10.30957/lingua.v13i2.181

Setyawan, B. W. (2019). Fenomena Penggunaan Unggah-Ungguh Basa Jawa Kalangan Siswa Smk Di Surakarta. Widyaparwa, 46(2), 145-156. https://doi.org/10.26499/wdprw.v46i2.200

Spencer, S., Clegg, J., \& Stackhouse, J. (2013). Language, social class and education: Listening to adolescents' perceptions. Language and Education, 27(2), 129-143. https://doi.org/10.1080/09500782.2012.760585

Tobing, R. L. (2015). Tingkat Tutur dalam Budaya "Jawa" dan "Batak": Analisis SosioPragmatik. Diksi, 14(2), 102-110. https://doi.org/10.21831/diksi.v14i2.6592

Wibawa, S. (2005). Identifikasi Ketidaktepatan Penggunaan Unggah Ungguh Bahasa Jawa Mahasiswa Program Studi Pendidikan Bahasa Jawa. Litera, 4(2), 149-158. https://doi.org/https 